Jurnal Lakon, 5 (1) 2016

(53-62)

\title{
MENEBAR BENIH KEBENCIAN MELALUI VISUALISASI 'BANCI’ KARTUN BENNY DAN MICE
}

Throwing the Seeds of Homophobia through the Visualisation of 'Banci' in Benny and Mice Cartoon

\section{ANIENDYA CHRISTIANNA}

\author{
Program Studi Desain Komunikasi Visual \\ Fakultas Seni dan Desain, Universitas Kristen Petra \\ Jl. Siwalankerto 121-131, Surabaya \\ e-mail: aniendya@petra.ac.id
}

\begin{abstract}
Cartoon with its concise, simple and attractive characteristic allows the reader to digest the ideas of the cartoonist. As one of the products of mass media, a cartoon is never neutral and value-free, it oftenly carries an ideology. Culture and the domination of an ideology contribute to the production process of the symbols that are articulated in a cartoon. This qualitative research used a methodology of critical study based on image-based research, which reveals the visual image as a research foundation. In the process of interpretation, the researchers are conducting a dialect with the text as an object. Then analyze it so that it becomes cohesive. After that, it could obtaine a relative reality. Benny and Mice cartoon implicitly states that heterosexuals are the 'normal' sex relationships. Beyond that, is a deviation. Deserves to be blamed, humiliated even ridiculed. Benny and Mice cartoon show that transsexual / transvestite / transgender as a source of fear. The package of it pictorial and verbal language wrapped in hyperbole and joke, and becomes the 'seeds' of homophobia amid the hegemony of heterosexual community.
\end{abstract}

Keywords: Cartoons, Gender, Homophobia

\begin{abstract}
Abstrak: Kartun dengan karakteristik yang ringkas, sederhana dan menarik memungkinkan pembaca untuk mencerna ide-ide dari kartunis. Sebagai salah satu produk media massa, kartun tidak pernah netral dan bebas nilai, sering kali membawa ideologi. Budaya dan dominasi ideologi berkontribusi pada proses produksi simbol-simbol yang diartikulasikan dalam kartun. Penelitian kualitatif ini menggunakan metodologi studi kritis berdasarkan penelitian berbasis gambar, yang mengungkap citra visual sebagai landasan penelitian. Dalam proses interpretasi, para peneliti melakukan dialek dengan teks sebagai objek. Kemudian, peneliti menganalisanya sehingga menjadi kohesif sehingga dapat memperoleh realitas yang relatif. Kartun Benny dan Mice secara implisit menyatakan bahwa heteroseksual adalah hubungan seks yang 'normal'. Di luar itu, ada penyimpangan, pantas disalahkan, dan dipermalukan bahkan diejek. Kartun Benny and Mice menunjukkan bahwa tanseksual / waria / transgender dianggap sebagai sumber ketakutan. Paket gambar dan bahasa verbal tersebut dibungkus dengan hiperbola dan lelucon, dan menjadi 'benih' homofobia di tengah hegemoni komunitas heteroseksual.
\end{abstract}

Kata-kata Kunci: Gender, Homofobia, Kartun

Jurnal Lakon: Kajian Sastra dan Budaya

e-ISSN: 2527-4899; p-ISSN 2252-8954 


\section{PENDAHULUAN}

Kelompok minoritas atau kelompok masyarakat yang berbeda secara signifikan dari konstruksi sosial lingkungan masyarakat sekitar, kerapkali menerima perlakuan yang diskriminatfif. Perbedaan ekstrem tersebut dapat mengenai suku bangsa, agama, ras, warna kulit, kelas sosial, orientasi sosial dan atau identitas gender. Dalam perspektif umum di Indonesia yang heteroseksual, waria (wanita-pria) dianggap sebagai sebuah penyimpangan perilaku, sebagai penyakit masyarakat, yang harus segera disembuhkan (Ida, 2010: 223). Konstruksi sosial tentang seksualitas telah ada dan dilestarikan melalui normanorma yang berlaku dalam masyarakat, antara lain norma agama dan norma sosial. Norma tersebut diamini oleh sebagian besar masyarakat, dan sifatnya yang mutlak tidak dapat diganggugugat. Tafsir tunggal agama tentang heteroseksual tidak mendapatkan tempat bagi kelompok inferior. Konstruksi sosial tersebut menghasilkan sebuah pemahaman tentang oposisi biner antara laki-laki dan perempuan, sekaligus menegaskan kategori diluar keduanya. Proses sosialisasi oleh kelompok yang dominan telah membentuk sebuah pemahaman yang antipati pada kelompok-kelompok dengan orientasi gender berbeda dari paham yang dominan, yakni heteronormativitas, berpaham patriarkhi.

Secara fisik waria adalah laki-laki lengkap dengan kelamin yang normal, tetapi merasa dirinya perempuan, dan berpenampilan tidak ubahnya seperti perempuan (Koeswinarno, 2004: 11). Sesuai dengan pernyataan Dede Oetomo (1996: 261; 2000: 54) bahwa waria adalah penggabungan dari feminitas dan maskulinitas, oleh karena itu disebut sebagai The Third Gender. Atau dengan kata lain waria adalah perempuan yang terperangkap dalam tubuh pria.

Konstruksi sosial tentang seksualitas menjadikan kelompok minoritas mendapat perlakuan yang diskriminatif berupa pelecehan, penolakan, pemberantasan bahkan regulasi yang semakin menyudutkan posisi mereka. Lebih lanjut tentang upaya diskriminatif oleh Pierre Bourdieu (1998: 165) dinyatakan bahwa penindasan yang dilakukan kini seolah-olah tak tampak. Keberadaan kaum waria yang telah diketahui dan diakui ditindas sedemikian rupa dengan menanamkan stigma atas mereka.

Konstruksi sosial selalu sarat dengan kepentingan (Bungin, 2008: 192). Pada dasarnya, manusialah yang membentuk imaji dunia. Sebuah teks tidak dapat didefinisikan sebagai refleksi dari realitas semata, tetapi ia harus dipandang sebagai sebuah konstruksi atas realitas. Foucault (1980: 142) menegaskan bahwa waria merupakan kategori yang terkonstruksi sedemikian rupa ditengahtengah masyarakat. Akibat yang dihasilkan dari konstruksi tersebut adalah waria dipatologisasikan sebagai sesuatu yang menyimpang, sebagai sesuatu yang tidak patut. Konteks sosial budaya saat ini membuat waria dimarginalkan bahkan dikriminalisasikan. Waria diasosiasikan dengan perilaku berhubungan seksual yang menyimpang dan abnormal. Lain halnya dengan gay dan lesbian, waria memiliki posisi sosial yang 'unik'.

Karena secara historis, waria telah lama diketahui dalam kebudayaankebudayaan Indonesia, seperti bissu dari Bugis, wanita-pria yang dahulu dipercaya oleh masyarakat Bugis sebagai penjaga dan

Jurnal Lakon: Kajian Sastra dan Budaya 
pemelihara pusaka kerajaan, istana sekaligus sebagai perantara manusia dengan Tuhan (Oetomo, 2006: 3). Adapula bassir dari Dayak Ngaju, yang juga menjadi perantara dunia dengan para arwah nenekmoyang, sedangkan di masyarakat Toraja Pamona terdapat tadu mburake, yang memimpin ritus-ritus spiritual (Oetomo, 2006: 4). Dalam perkembangan selanjutnya, menteri agama Alamsjah Ratu Prawiranegara (Budiawan, 2015: 86) mengganti istilah wadam (wanita-adam) menjadi waria (wanita-pria). Pertimbangan ini karena nama 'adam' merujuk pada Nabi Adam. Keputusan tersebut secara regulasi setidaknya telah mengindikasikan bahwa keberadaan waria diakui warganegara sekaligus sebagai manusia yang setara dengan manusia lainnya.

Kartun Benny dan Mice melukiskan tentang peristiwa-peristiwa harian yang digambarkan secara menyenangkan, ringan dan menarik. Kartun biasanya hanya mengungkap esensi pesan dalam gambar sederhana, tanpa detail dan bersifat menghibur. Kondisi umum perkotaan seperti tentang gadget, kondisi sosial, ekonomi bahkan tentang isu-isu lingkungan. Eksistensi waria ditengahtengah masyarakat pun tak luput dari goresan kartun Benny dan Mice. Kartun Benny dan Mice sebagai salah satu bentuk komunikasi visual, berusaha untuk menyuguhkan suatu bentuk gambar intepretatif dengan menggunakan simbolsimbol pesan secara cepat dan ringkas. Simbol-simbol yang diartikulasikan dalam kartun Benny dan Mice 'dicurigai' mengandung makna-makna bahkan ideologi yang sarat hegemoni.

Berdasarkan paparan diatas, artikel ini hendak mengkaji dua hal, yakni (1) bagaimana male gaze direpresentasikan dalam kartun Benny dan Mice?; dan (2) Bagaimana ideologi tektstual didalamnya?

\section{LANDASAN TEORI}

Kartun merupakan sebuah gambar yang bersifat representasi atau simbolik, sebuah kartun bisa dijabarkan sebagai sebuah cerita panjang, maupun cerita singkat. Kartun memiliki potensi setara dengan sejuta kata-kata yang lahir dari beribu pikiran yang terpendam (Tanudjaja, 2001: 170). Lebih lanjut oleh Hartanto (2009: 86) bahwa kartun merupakan wacana visual dalam media massa yang sarat dengan tanda-tanda pictorial. Kartun dengan karakteristiknya yang ringkas, sederhana dan menarik memudahkan pembaca mencerna hasil pemikiran kartunisnya. Kemampuannya yang sarat dengan bahasa gambar dan minim teks, mendorong kartun menjadi mass culture selayaknya tontonan televisi. Sebagai salah satu produk media massa, kartun tidak pernah netral dan bebas nilai, ia kerapkali mengusung suatu ideologi. Ideologi media tidak lepas dari konteks dimana media tersebut diproduksi dan dikonsumsi. Budaya dan paham dominan ikut berkontribusi dalam proses produksi simbol-simbol yang diartikulasikan dalam sebuah kartun.

Mula-mula tentang istilah 'banci': dalam Warias, National Transvetite, Tom Boellstorff (2005) menyatakan bahwa terdapat sebuah pertunjukan tari yang bertajuk 'Bantji Batavia' pada tahun 1830an. Pertunjukan itu adalah salah satu budaya popular pada masanya, dimana terdapat laki-laki muda yang mengenakan pakaian seperti perempuan. Seiring zaman, terminology 'banci' mengalami peyorasi, bermakna hinaan kepada laki-laki yang bertingkah feminin. Kata 'banci' kerapkali

Jurnal Lakon: Kajian Sastra dan Budaya 
digunakan sebagai hinaan atau makian oleh masyarakat homophobic kepada laki-laki yang berperilaku 'tidak seharusnya'. Maskulinitas adalah nilai yang dipuja oleh masyarakat dominan dan selalu diasosiasikan dengan laki-laki. Menjadi maskulin berarti dominan dan superior. Sementara itu, feminitas sebagai kutub seberangnya dianggap yang sekunder, inferior dan selalu diasosiasikan dengan perempuan, pihak yang lebih rendah, lebih tak berdaya daripada laki-laki. Oleh karena itu, ketika laki-laki berperilaku, bertingkah, ataupun bertutur kata feminin, serta merta ia akan direndahkan.

Adrienne Rich dalam konsepnya Compulsory heterosexuality (heteroseksualitas yang diwajibkan) menyebutkan bahwa praktek-praktek sosial- budaya dibentuk untuk melestarikan konsep heteroseksualitas, sehinggap dianggap alami dan natural. Konsep ini mempolarisasi gender menjadi dua kategori: maskulin diasosiasikan pada lakilaki dan feminitas pada perempuan. Keduanya bertautan berdasarkan relasi kuasa (power relations). Maskulinitas 'dianggap' sebagai superior dan feminitas sebagai inferior. Dikotomi inilah yang menjadi basis heteronormativitas. Ketika laki-laki tidak mengikuti norma maskulinitas 'yang benar', maka bulanbulanan/bully-an menjadi upahnya.

\section{METODOLOGI PENELITIAN}

Penelitian ini menggunakan pendekatan kualitatif. Karena dalam penelitian menghubungkan teks tertentu dengan sistem pesan dimana ia beroperasi. Dengan cara mengulas unsur teks yang bekerja sama dan berinteraksi dengan pengetahuan kultural untuk menghasilkan makna, "what is the nature of reality".
Penelitian kualitatif ini menggunakan metode studi kritis dengan image based research, yakni mengungkapkan visual image sebagai dasar penelitian. Dalam proses interpretasi, peneliti akan melakukan proses dialektikanya dengan teks sebagai obyek.

Kemudian dilakukan analisis
sehingga menjadi suatu kesatuan. Selanjutnya akan diperoleh realitas yang bersifat relatif. Adapun langkah-langkah penelitian yang akan dilakukan adalah sebagai berikut: Pertama, kartun Benny dan Mice sebagai objek penelitian akan didokumentasikan dan diamati secara seksama. Kedua, Mengamati dan menyeleksi kartun Benny dan Mice untuk dianalisis menggunakan pendekatan metodologi visual, khususnya pada area site of image itself untuk memperoleh tandatanda yang diartikulasikan dalam setiap tampilan tokohnya. Proses pengamatan meliputi observasi mendalam pada Representation of body (gender, tatanan rambut), bentuk dan ukuran tubuh, penampilan); Representation of manner (mimik wajah dan kontak wajah dan pose/gestur); Representation of activity; dan Property and setting (latar depan dan latar belakang). Peneliti melakukan interpretasi, pemaknaan dan pemahaman terhadap objek visual yang diamati. Dengan kemampuan analisis kritis peneliti membaca dan mengurai makna satu per satu dari komposisi yang membentuk dan melekat pada objek gambar visual yang ada.

Penelitian dengan perspektif site of the image itself mempunyai konsekuensi bahwa peneliti harus mengamati dengan seksama visual image yang dikaji untuk memperoleh pemahaman atas efek-efek visual yang nampak (denotatif). Kemudian peneliti memakai pendekatan teoritis yang

Jurnal Lakon: Kajian Sastra dan Budaya e-ISSN: 2527-4899; p-ISSN 2252-8954 
paling relevan dan memungkinkan sesuai dengan karakteristik visual image dan temuan-temuan pada tataran efek-efek visual, misalnya semiologi untuk melihat relasi makna yang berkaitan dengan hal-hal lain yang tersembunyi dalam visual image.

Relasi antara makna gambar dengan latent value menjadi artikulasi atas hal- hal tertentu yang menjadi ungkapan makna terdalam sebagai implementasi aspek konotasi. Hal ini menjadikan medotodologi visual bukanlah hal yang secara signifikan berbeda dengan metode lain yang selama ini digunakan untuk menyingkap makna representasi atas sebuah teks/ visual image. Perbedaan yang nampak ada pada aspek cara dan aspek modality, yakni teknologi, komposisi dan sosial pada bagaimana representasi itu diungkap.

Dalam visual metodologi, peneliti bebas menentukan dimana titik pijakan. Metodologi visual sebagaimana diungkapkan oleh Rose, hanya sebagai cara untuk menyelidiki makna dan efek dari visual image suatu penelitian yang melibatkan sebuah teks gambar.

\section{PEMBAHASAN}

\section{Menertawakan Waria Melalui Kartun}

Media seringkali terjebak dalam keberpihakan. Sehingga dapat disimpulkan bahwa media tidak sekedar penanda budaya popular, tetapi sekaligus sebagai penanda ideologis (Storey, 2001:7). Pada titik inilah, kartun Benny dan Mice 'dicurigai' telah menyuguhkan hiburan sarat ideologi dominan yang bias. Kartun Benny dan Mice dari harian Kompas telah menerbitkan empat buku komik, yakni Lagak Jakarta 1 dan 2 (2007), Jakarta Luar Dalem (2007), 100 tokoh yang mewarnai Jakarta (2008), dan Talk About Hape
(2008). Kartun Benny dan Mice hadir sebagai media hiburan sekaligus media kritik sosial terhadap fenomena yang terjadi dalam kehidupan masyarakat perkotaan. Sebelum dibukukan, kartun Benny dan Mice adalah sebuah seri strip komik yang terbit setiap hari minggu di harian Kompas. Cerita kartun Benny dan Mice memiliki latar belakang perkotaan metropolitan Jakarta dan dikemas dengan gaya hiperbola yang khas. Kerapkali pengungkapan-pengungkapan dalam kartun tersebut layaknya seperti bercermin. Kartun Benny dan Mice yang lugas dan hiperbolis tersebut menjadi cerminan sekaligus kontrol sosial yang "menyenangkan" bagi beragam fenomena di perkotaan. Keberadaan waria, tak luput menjadi sorotan realitas sosial yang digambarkan secara lugas dan terperinci.

Salah satu teori budaya visual yang mengemukakan tentang bagaimana cara seseorang melihat orang lain berdasarkan gender, usia, posisi yang melibatkan aspek kejiwaan adalah gaze. Menurut Chandler (2008) gaze, adalah bagian budaya visual yang menekankan pada aspek visual penampilan manusia. Gaze berkaitan dengan cara manusia atau tokoh mirip manusia untuk dipertontonkan. Kartun Benny dan Mice memaparkan gambaran waria dengan cara yang unik, spesifik dan cenderung hiperbola (gambar 1). 


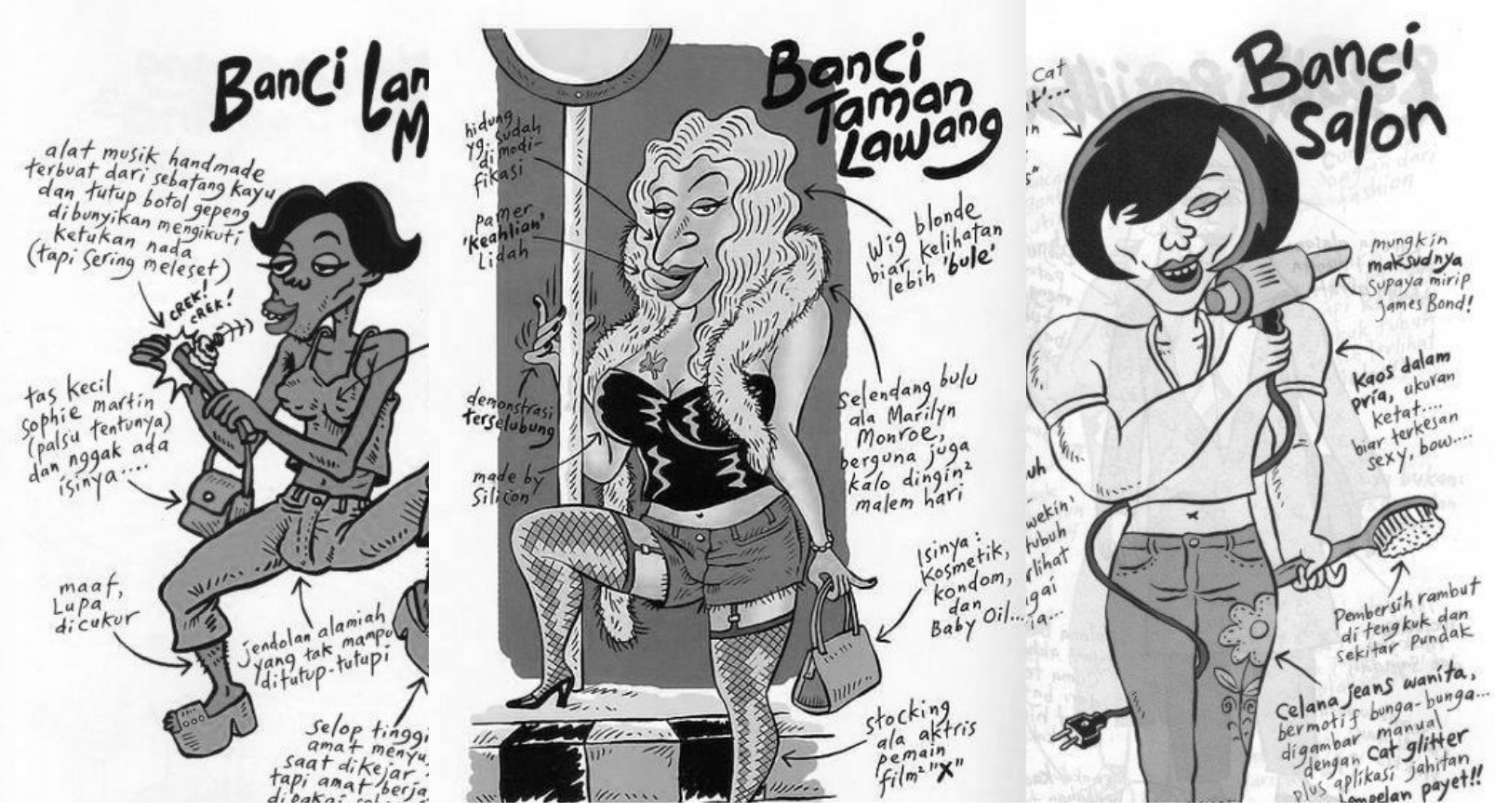

Gambar 1. Banci dalam Kartun Benny dan Mice

(Sumber: Dokumentasi pribadi)

'Banci' dalam kartun Benny dan Mice adalah contoh bagaimana praktek disiplin tubuh dan gender bekerja dibalik tampilan gambar kartun yang lucu. Jelaslah bahwa kartun Benny dan Mice melanggengkan konsep heteroseksualitas tanpa kekerasan yang kentara, melainkan melalui hinaan yang 'lucu'. Hinaan 'banci' meyakinkan bahwa maskulinitas adalah yang powerfull, tidak emosional, heteroseksual, dominan serta berhak mencemooh yang tidak sesuai. Singkatnya, merendahkan orang lain untuk meninggikan diri.

Stigma dan stereotip negatif seringkali dilekatkan pada orientasi seksual tertentu, utamanya yang tidak 'sesuai' dengan norma-norma umum. Homoseksual seringkali disamaartikan dengan pedofilia, pencemburu, pesakitan, tidak normal bahkan pembunuh. Pada level berikutnya, homoseksual di perkotaan tidak sekedar menerima kekerasan secara fisik dan dikriminalisasi, tetapi juga mengalami kekerasan secara simbolik dan ekonomi. Kartun Benny dan Mice mengartikulasikannya secara terperinci namun beroperasi 'halus' dibalik lelucon. 'Banci Lampu Merah', 'Banci Taman Lawang' dan 'Banci Salon' menunjukkan fenomena kelompok homoseksual dari kelas menengah-bawah yang kesulitan dalam memperoleh pekerjaan formal. Keterbatasan pendidikan dan sumber daya ekonomi menambah kerentanan kaum minoritas ini. 'Banci Lampu Merah' dideskripsikan dengan tampilan fisik yang kurus dan tak terawat. Tulang pipi menonjol, rambut kaki yang menyembul di balik celana, tone kulit yang gelap sembari membawa 'alat musik handmade' dimaknai sebagai manusia gender ketiga dengan keterbatasan ekonomi yang kekurangan nutrisi, bekerja diluar ruangan dan terus menerus terpapar matahari. 
'Banci Taman Lawang' setali tiga uang dengan 'Banci lampu merah', bedanya postur tubuh yang lebih berisi. Pakaian, stocking jaring, high heels, rambut warna terang, tas jinjing dan make up setidaknya memberi warna dibandingkan 'Banci lampu merah'. Gestur kedua kaki yang terbuka serta juluran lidah sembari memegang tiang rambu-rambu lalu lintas, mengarahkan pemaknaan khalayak pada sebuah profesi (yang dianggap) maksiat. Taman Lawang adalah suatu kawasan yang dikenal sebagai tempat berkumpulnya waria di Jakarta. Masyarakat berpendapat, bahwa Taman Lawang tidak sekedar wahana berkumpul para waria, tetapi sekaligus sebagai pusat prostitusi. Padahal, pada mulanya, tahun 1973, Gubernur DKI Ali Sadikin kala itu, membuka akses taman kepada waria untuk berkumpul, menyuarakan pendapat atau sekedar melakukan olahraga dan relaksasi. Gubernur saat itu, menilai bahwa wadam (sebutan waria pada tahun 1970-an) berhak memperoleh hak-hak yang sama dengan warga Jakarta lainnya. Namun, pengertian Taman Lawang sekarang telah mengalami peyorasi (penurunan makna)

'Banci Salon' ditampilkan sebagai individu yang 'membingungkan'. Ukuran dan postur tubuh digambarkan sedemikian gempal, tetapi mengenakan pakaian berukuran lebih kecil (hingga pinggang dan pusar terekspos). Kaum homoseksual seringkali ditampilkan sebagai sosok yang maskulin, tubuh kekar, tetapi sangat menjaga kerapian penampilan. Dalam the Body in Society, Howson memaparkan bahwa tubuh adalah media untuk manusia berinteraksi dengan dunia dan orang-orang disekitarnya. Tubuh yang pada mulanya terberi secara biologis tidak dapat dilepaskan dari makna sosial. Manusia berpenis dituntut untuk berperilaku dan bertubuh tegap, berotot. menjadi sebuah 'kebingungan tersendiri' ketika 'banci salon' hadir dengan tubuh (yang seharusnya) milik maskulin, melebur dengan gestur dan mimik 'milik' feminin. Tubuh tidak bisa dipisahkan dari makna sosial. Diatas tubuh biologis, dibangunlah tubuh sosial. Sejak lahir, manusia diidentifikasi berdasarkan alat kelamin yang menempel di tubuh. Selanjutnya, diarahkan dan dididik untuk mengikuti suatu peran gender tertentu sesuai dengan alat kelamin. Dengan demikian, pemahaman kita tentang peran gender (bagaimana seharusnya berperilaku, berpakaian dan bertubuh) bukanlah sesuatu yang alamiah, melainkan suatu konstruksi sosial. Budaya populer tidak dipungkiri mempunyai andil yang besar terhadap pembentukan stereotip dan pemahaman terhadap suatu hal Kerangka polaritas inilah yang menjadikan hubungan heteroseksual sebagai sesuatu yang 'normal' dan 'alamiah'. 'Banci Salon' salah satu lelucon anomali tersebut.

Menjadi feminin atau maskulin adalah sebuah upaya konstruksi sosial yang dilekatkan pada individu berdasarkan identitas seksual/alat kelamin yang menempel di tubuh. Konstruksi sosial tersebut mempengaruhi peran sosial, tingkah laku dan pekerjaan. Judith Butler (1993) menunjukkan dalam performativity adalah sebuah konsep maskulinitas dan feminitas yang tidak statis, sangat dipengaruhi oleh konstruksi yang ada sebelumnya. Kartun Benny dan Mice membangun suatu pemahaman bahwa waria/banci/homoseksual adalah lawan dari heteroseksual. Suatu kategori tidak akan berarti jika tanpa kategori lainnya, sama seperti 'gelap' tidak akan berarti jika tanpa 'terang'. Kartun Benny dan Mice secara implisit menyatakan bahwa heteroseksual adalah hubungan lawan jenis 
yang 'normal'. Diluar itu, dianggap sebagai penyimpangan. Layak untuk dipersalahkan, dihina pun ditertawakan. Dan khalayak pun mengamininya sebagai sebuah 'kebenaran yang mutlak'.

\section{Menebar Benih Kebencian: Homophobia}

Kartun dengan karakteristiknya yang mudah dicerna melalui perpaduan bahasa gambar dan bahasa verbal, dapat dinikmati oleh segala umur bahkan menjadi bacaan keluarga. Sebagai produk budaya massa, baik sengaja maupun tidak disengaja, ia telah menjadi bagian dari proses penyebaran ideologi. Kartun 'dicurigai' menampilkan, menyebarkan stereotip serta merefleksikan nilai dan kepercayaan fundamental dalam masyarakat. lelucon, justru menjadi 'benih-benih' homophobia tumbuh ditengah hegemoni masyarakat heteroseksual. Homophobia tumbuh dengan prasangka dan kekurangpahaman tentang sikap dan perilaku seksual manusia. Kartun 'Digodain Banci' memperlihatkan kaum waria/banci sebagai sosok yang agresif, penggoda, dan memiliki hasrat seksual yang liar. Keberadaannya di ranah publik menjadi sebuah 'penyakit' yang ditakuti.

Homophobia adalah ketakutan yang berlebihan untuk berada dekat, berinteraksi dan berhubungan dengan homoseksual, karena dianggap dapat memberikan pengaruh yang negatif (Polimeni, 2000). Homophobia muncul karena adanya konsep heteroseksual, yang berasumsi bahwa seluruh manusia seharusnya berhubungan secara seksual dengan lawan jenisnya. Sehingga
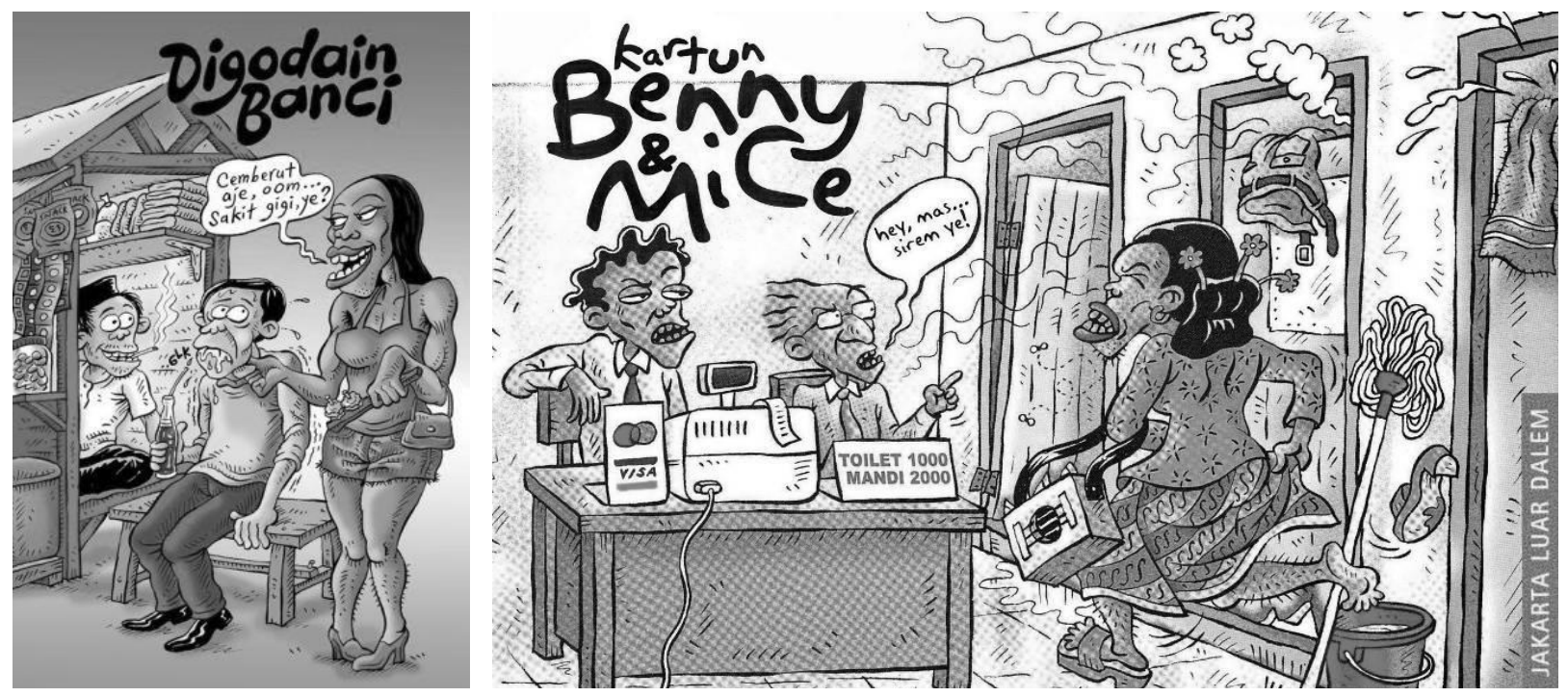

Gambar 2. Banci dalam Kartun Benny dan Mice

(Sumber: Dokumentasi pribadi)

Kartun Benny dan Mice keberadaan kaum gay, lesbian, biseksual memperlihatkan bahwa maupun transgender dianggap sebagai waria/banci/transgender sebagai sumber ancaman karena 'ketidaklazimannya'. ketakutan. Balutan bahasa gambar dan bahasa verbal yang hiperbola berbalut 
'Ketidaklaziman' menimbulkan perilaku penolakan dalam berbagai wujud. Seperti yang ditampilkan dalam Kartun Benny dan Mice: "Digodain Banci" memperlihatkan bahwa waria memiliki kesulitan dalam memperoleh pekerjaan formal dalam masyarakat. 'Ketidaklaziman' mereka berimbas pada pencerabutan hak-hak sebagai manusia, salah satunya hak untuk bekerja secara formal. Untuk memperoleh sumber daya ekonomi, waria distereotipkan dengan profesi-profesi yang tidak formal, beroperasi dijalanan dan tanpa penghasilan yang tetap.

Penggambaran media dan budaya populer, tak dapat ditampik telah menjadi konsumsi luas sehari-hari, sehingga banyak mempengaruhi cara pandang masyarakat terhadap dunia. Pemberitaan media maupun diskusi-diskusi kaum intelektual di media massa, justru memperjelas wajah masyarakat yang homophobia. Media massa turut mengambil bagian dalam membangun persepsi terhadap sesuatu yang 'ideal' dan 'tidak ideal'. Setiap hari kita melihat, membaca dan mengamininya sebagai sesuatu yang 'taken for granted'. Dalam Buku Male Order, dituliskan bahwa homoseksualitas dan homophobia adalah konsep yang dikonstruksi secara historis. Sikap homophobia hadir dalam berbagai bentuk, mulai dari kekerasan secara fisik, verbal, psikologis bahkan kekerasan simbolik. Dasar dari perilaku diskriminatif tersebut adalah prasangka yang bermula dari pelabelan dan sterotip pada kaum LGBT. Kartun Benny dan Mice turut mengambil bagian dalam membangun prasangka tersebut dan secara tidak langsung telah melakukan kekerasan secara simbolik melalui artikulasi citra visual. Kartun Benny dan Mice yang dinikmati secara massal dimaklumi sebagai sebuah kebenaran yang mutlak dan patut untuk ditertawakan, dikesampingkan bahkan dihakimi.

\section{KESIMPULAN}

Sebagian besar masyarakat pada saat ini masih memiliki pemahaman heteronormativitas dan dikontrol oleh budaya patriarkhi dalam hal seksualitas, peran gender maupun ekspresi gender. Paham dan budaya tersebut bekerja secara mengakar tak terlihat dalam berbagai aspek kehidupan dan melalui berbagai media, salah satunya adalah kartun Benny dan Mice. Visualisasi Kartun Benny dan Mice tentang waria lebih banyak tidak menguntungkan eksistensi identitas waria di masyarakat. Waria adalah Sang Liyan dari fisik, gender dan preferensi seksual yang dianggap menyimpang dari norma nilai budaya, hukum dan agama. Kartun Benny dan Mice maupun media massa lainnya kerapkali mengedepankan tentang identittas dalam masyarakat yang ideal/yang seharusnya, dibandingkan gambaran masyarakat yang sesungguhnya. Pada akhirnya yang terjadi adalah sebuah ketimpangan. Waria menjadi korban stigmatisasi, yang seringkali dilecehkan di tempat umum, didiskriminasi dari komunitas masyarakat, tidak memperoleh kesempatan pendidikan dan pekerjaan formal, kesulitan administrasi dan birokrasi karena identitasnya yang tidak diakui, bahkan dikriminalisasi. Pemahaman tentang heteronormativitas dan budaya patriarkhi semakin mendominasi pola pikir masyarakat, melalui lelucon sekalipun. Apa yang diartikulasikan media populer ini pada akhirnya membawa dampak negatif yakni perlakuan yang diskriminatif terhadap waria. 
I hate the word 'homophobia'.

It's not a phobia. You are not scared. You are just cruel.

(Morgan Freeman).

\section{DAFTAR PUSTAKA}

Boellstorff, Tom. (2005). The gay Archipelago: Sexuality and Nation USA: Princeton University Press.

Bourdieu, Pierre. (1998). Dominasi Maskulin. Yogyakarta: Penerbit Jalasutra.

Bungin, Burhan. (2008). Konstruksi sosial media massa: kekuatan pengaruh media massa, iklan televisi dan keputusan konsumen serta kritik terhadap Peter L. Berger \& Thomas Luckmann. Jakarta Penerbit Kencana.

Chandler, Daniel. (2008). Notes on the Gaze. Mass Communication Department Humanities Division Ateneo de Davao University.

Foucault, Michael. (1980). Power and Strategies. New York: Pantheon.

Hartanto, Deddi Duto. Visual Image Benny dan Mice Versi Bluetooth Handsfree Representasi kaum Miskin Kota Jakarta. Jurnal NIRMANA vol. 11, no. 2, Juli 2009: 86-92 Jurusan Desain Komunikasi Visual. Fakultas Seni dan Desain Universitas Kristen Petra.

Ida, Rachmah. (2010). Respon Komunitas Waria Surabaya Terhadap Konstruksi Subyek Transgender di Media Indonesia. Surabaya: Departemen Komunikasi FISIP, Universitas Airlangga, tahun 2010, volumen 23, nomor 3, Hal: 221-228.

Koeswinarno. (2004). Hidup Sebagai Waria. Bantul: LKiS Yogyakarta.

Oetomo, Dede. (1996). Gender and Sexual Orientation in Indonesia. In
Fantasizing the Feminine in indonesia, edited by L. J. Sears. Urham: Duke University Press.

Oetomo, Dede. (2000). Masculinit in Indonesia: Genders, Sexualities, and Identities in a Changing Society. In Framing the Sexual Subject: the Politics of Gender, Sexuality and Power, edited by R. Parker, R. M. Barbosa and P. Anggleton. Barkeley: University of California Press.

Oetomo, Dede. (2006). Memperjuangkan Hak Asasi Manusia Berdasarkan Identitas Gender Dan Seksualitas Di Indonesia. Surabaya: Yayasan GAYa NUSANTARA.

Polimeni, Anne Maree. (2000). Homophobia Among Australian Heterosexuals: The Role Of Sex, Gender Role Ideology, And Gender Role Traits. Social Psychology Journal The Universiy of Iowa Volume 5, Issue 4, March 9, 2000.

Rich, Adrienne. (1980). Compuulsory Heterosexuality and Lesbian Excistence. London: Virago.

Rose, Gillian. (2003). Visual Methodologies.UK: Sage Publishing.

Storey, John. (2001). Cultural Theory and Popular Culture An Introduction. London: University of Sunderland.

Tanudjaja, Bing Bedjo. (2001). BentukBentuk Kartunal Sebagai Medium Penyampaian Pesan dalam Iklan. Jurnal NIRMANA vol. 4, no. 2, Juli 2002: 169-178 Jurusan Desain Komunikasi Visual. Fakultas Seni. 